\title{
EFEKTIFITAS MINUMAN JAHE DALAM MENGURANGI EMESIS GRAVIDARUM PADA IBU HAMIL TRIMESTER I
}

\author{
ANA ZAKIYAH, EMYK WINDARTIK, HERI TRI WIBOWO \\ DEPARTEMEN KEILMUAN DASAR KEPERAWATAN DAN KEPERAWATAN DASAR. \\ AKADEMI KEPERAWATAN BINA SEHAT PPNI KABUPATEN MOJOKERTO \\ ana_ppni@yahoo.com
}

\begin{abstract}
ABSTRAK
Kehamilan merupakan proses alami dan normal, namun pada umumnya ibu mengalami emesis gravidarum. Keluhan tersebut disebabkan oleh perubahan sistem endokrin yang terjadi selama kehamilan, terutama disebabkan oleh tingginya fluktuasi kadar Human Chorionic Gonadotrophin (HCG), keluhan tersebut biasanya terjadi pada 12-16 minggu pertama. Jahe adalah salah satu produk terapeutik yang diturunkan dari rhizoma, kandungan minyak atsiri yang bersifat aromatik dapat memberikan pengaruh langsung pada saluran gastrointestinal. Tujuan penelitian ini adalah mengetahui keefektifan pemberian minuman jahe pada ibu hamil yang mengalami emesis gravidarum. Desain penelitian ini adalah eksperimental one group pre test-post test design. Tehnik sampling yang digunakan adalah purposive sampling dengan jumlah 27 responden. Hasil analisis dengan wilcoxon sign rank test menunjukkan bahwa nilai $\mathrm{p}=0.00(\alpha<0.05)$. Pemberian minuman jahe dengan dosis yang tepat efektif dalam mengurangi emesis gravidarum pada ibu hamil trimester I karena kandungan minyak atsiri yang bersifat aromatik memberikan pengaruh langsung pada saluran gastrointestinal, sedangkan efek antiemetik pada jahe disebabkan oleh kerja antikolinergik dan antihistamin. Jahe menjadi salah satu alternatif untuk mengurangi gejala emesis gravidarum dengan berbagai jenis sediaan/kemasan sehingga lebih menarik tanpa mengurangi khasiat yang terkandung di dalamnya.
\end{abstract}

Kata kunci: jahe, emesis gravidarum, morning sickness

\section{ABSTRACT}

Pregnancy is a natural and normal process, but generally, women experience morning sickness. The complaints are caused by endocrine system changes that occur during pregnancy, mainly caused by fluctuations in the levels of HCG (human chorionic gonadotrophin), such complaints usually occur in the first 12-16 weeks. Ginger is one of the therapeutic products derived from rhizomes, atsiri oil content that is both aromatic can provide a direct influence on the channel gastrointestinal. Aim of this study was to determined the effectiveness of the provision of ginger ale in pregnant women who experience morning sickness. This is an experimental one group pretestposttest design. Sampling technique used purposive sampling with 27 respondents. The results of the analysis with the wilcoxon signed rank test showed that the $p=0.00(\alpha<0.05)$. Giving ginger drink with the right dose effective in relieving morning sickness in the first trimester pregnant women because it contains aromatic oils that are atsiri give direct effect on the gastrointestinal tract, whereas the antiemetic effect of ginger is caused by anticholinergics and anthistamin work. Ginger became one alternative to reduce the symptoms of morning sickness with various types of preparation/ packaging making it more attractive without reducing the benefits contained therein.

Keywords: ginger, morning sickness, emesis gravidarum 


\section{PENDAHULUAN}

Kehamilan merupakan proses normal. Ibu hamil akan memasuki tahap 3 bulan yang lazim disebut trimester atau triwulan. Awal kehamilan yang disebut trimester 1 yaitu dimana ibu masuk pada 3 bulan pertama. Ibu hamil pada trimester I ini akan mengalami perubahan emesis gravidarum yang umum dialami oleh $50 \%$ wanita hamil. ${ }^{1}$

Sebagian gejala tersebut sering muncul pada wanita hamil saat bangun tidur yang disebut morning sickness, akan tetapi pada sebagian yang lain, gejala mual dan muntah dapat terus berlanjut sepanjang hari. Mengutip studi prospektif Lacroix et al pada tahun 2000 yang menemukan bahwa $1,8 \%$ ibu hamil mengalami mual pada pagi hari, sedangkan pada $80 \%$ ibu hamil mulai dapat berlangsung mual dan muntah sepanjang hari. ${ }^{9}$ Mual dan muntah selama kehamilan biasanya disebabkan oleh perubahan sistem endokrin yang terjadi selama kehamilan, diantaranya karena tingginya fluktuasi kadar HCG (Human Chorionic Gonadotrophin). Muntah diawali dengan stimulasi pusat muntah di medula yang mengendalikan otot polos dalam dinding lambung dan otot skeletal di abdomen serta sistem pernafasan, dan zona pemicu kemoreseptor berada diluar sawar darah otak zona pemicu kemoreseptor. Kemoreseptor tersebut juga bertanggung jawab atas terjadi mual dan muntah akibat pergerakan. Stimulus dalam zona pemicu kemoreseptor dihantarkan ke pusat muntah yang menyebabkan otot dalam saluran gastrointestinal dan pernafasan memulai terjadinya muntah. ${ }^{10}$

Ibu hamil merasakan bahwa mual dan muntah merupakan hal yang biasa terjadi. Sebagian lagi merasakan bahwa mual dan muntah merupakan suatu hal yang tidak nyaman dan mengganggu aktivitas sehari-hari bahkan banyak dari wanita hamil yang harus mengkonsumsi obat-obatan atau tindakan alternatif lain untuk mengatasi mual dan muntah. Obat-obatan yang sering diberikan biasanya mengandung efek anti mual seperti vitamin B6, namun bahan-bahan ini dilaporkan memiliki efek samping seperti sakit kepala, diare dan mengantuk. ${ }^{4}$

Nasihat yang paling baik untuk ibu hamil adalah bahwa tidak ada obat yang harus digunakan selama kehamilan, tetapi beberapa penyakit ringan yang umum sering memerlukan terapi untuk membuat ibu merasa nyaman. ${ }^{6}$ Jahe adalah pengobatan herbal yang telah digunakan dalam fitoterapi Eropa dan dalam pengobatan tradisional Cina karena kandungan karminatifnya. Produk terapeutik diturunkan dari rhizoma yang diyakini mengandung analgesik, anti inflamasi, anti trombotik, spasmolitik, absorben dan minyak atsiri yang bersifat aromatik dan dapat memberikan pengaruh langsung pada saluran gastrointestinal. ${ }^{7}$ Efek anti emetiknya diduga disebabkan oleh kerja antikolinergik dan anti histamin. ${ }^{9}$

Vutyavanich et al (2001) melakukan survei secara acak kepada 70 wanita dengan usia kehamilan kurang dari 17 minggu yang mengonsumsi jahe sebanyak 1 gr per hari atau mendapatkan placebo yang identik dengan jahe selama empat hari, dan mengukur jumlah episode muntah per 24 jam dan keparahan mual dengan menggunakan skala analogi visual. Terdapat perbaikan bermakna dalam mengatasi gejala mual dan muntah di kelompok jahe jika dibandingkan dengan kelompok placebo, sehingga hal ini menyebabkan mereka berkesimpulan bahwa jahe merupakan pengobatan yang efektif untuk meredakan mual dan muntah dalam kehamilan. Penelitian sebelumnya yang dilakukan oleh Fischer Rasmussen et al (1991) menunjukkan jahe dapat efektif dalam mengurangi gejala hipermesis gravidarum pada wanita hamil jika dibandingkan dengan placebo. ${ }^{9}$

Saat ini minat menggunakan terapi komplementer untuk mengatasi gejala kehamilan dan berbagai aspek persalinan telah berkembang. ${ }^{9}$ Hasil studi pendahuluan pada tanggal 8 Februari 2015 di Desa Dlanggu Mojokerto ditemukan sebanyak $10 \mathrm{ibu}$ hamil trimester pertama dan mereka mempunyai pengetahuan yang kurang tentang manfaat jahe dalam mengurangi mual dan muntah sebanyak 8 orang $(80 \%)$. Hal ini diperkuat dengan data bahwa ibu hamil yang sering mengkonsumsi jahe hanya 2 orang (20\%), itu pun jahe sebagai bumbu pelengkap masakan yang ibu masak, sedangkan dari $10 \mathrm{ibu}$ hamil yang mengalami mual muntah sebanyak 9 orang (90\%) dan ibu hamil tanpa mual muntah hanya 1 orang (10\%).

Berdasarkan uraian tersebut peneliti tertarik untuk melihat keefektifan pemberian minuman jahe pada ibu hamil yang mengalami emesis gravidarum dan penelitan 
ini nanti akan dapat digunakan tenaga kesehatan sebagai salah satu pedoman pemberian tindakan untuk mengurangi emesis gravidarum.

\section{METODE}

Desain penelitian yang digunakan adalah eksperimental one group pre test-post test design. Populasinya adalah sebanyak 27 ibu hamil trimester I di BPM Yayuk S, Desa Dlanggu Kabupaten Mojokerto.

Pengambilan sampel dengan menggunakan teknik purposive sampling. Instrumen yang digunakan untuk mengukur derajat emesis gravidarum yaitu Analogy Visual Scale. Setiap responden diberi perlakukan selama 4 hari dengan memberikan minuman jahe di saat pagi hari, sebelum dan sesudah diberikan perlakuan diukur derajat emesis gravidarum yang dialami responden.

HASIL PENELITIAN

Data umum

Tabel 1 Karakteristik berdasarkan status gravida.

\begin{tabular}{llrr}
\hline No & Status Gravida & Jumlah & $\mathbf{( \% )}$ \\
\hline 1 & Primi gravida & 18 & 67 \\
2 & Multi gravida & 9 & 33 \\
\hline & Total & 27 & 100 \\
\hline
\end{tabular}

Responden dalam penelitian ini sebagian besar primi gravida sebanyak 18 responden $(67 \%)$.

\section{Data Khusus}

Tabel 2 Derajat Emesis Gravidarum sebelum dan sesudah pemberian minuman jahe pada ibu hamil trimester I bulan Mei 2015.

\begin{tabular}{rcrr}
\hline No & $\begin{array}{c}\text { Derajat } \\
\text { emesis }\end{array}$ & Pre test & Post test \\
\hline 1 & Ringan & $0 \%$ & $96.3 \%$ \\
\hline 2 & Sedang & $96.3 \%$ & $3.7 \%$ \\
\hline 3 & Berat & $3.7 \%$ & $0 \%$ \\
\hline & Total & $100 \%$ & $100 \%$ \\
\hline
\end{tabular}

Hasil penelitian menunjukkan adanya penurunan prosentase derajat emesis gravidarum pada ibu hamil trimester I.

Hasil analisis dengan wilcoxon sign rank test menunjukkan Ho ditolak dengan nilai $\mathrm{p}=0.00 \quad(<\alpha=0.05)$, sehingga dapat disimpulkan bahwa pemberian minuman jahe efektif dalam mengurangi emesis gravidarum pada ibu hamil trimester I di BPM Yayuk,S Desa Dlanggu Kabupaten Mojokerto.

\section{PEMBAHASAN}

Derajat Emesis Gravidarum sebelum pemberian minuman jahe pada ibu hamil trimester I di Desa Dlanggu Kabupaten Mojokerto.

Hasil penelitian menunjukkan ibu hamil trimester I seluruhnya mengalami emesis gravidarum pada tingkatan sedang, kecuali 1 responden mengalami emesis gravidarum berat. Emesis Gravidarum adalah mual dan muntah yang umum dialami oleh wanita hamil dan biasanya sering terjadi pada trimester pertama sehingga ibu hamil sering terganggu aktivitasnya. ${ }^{3}$ Mual dan muntah selama kehamilan biasanya disebabkan oleh perubahan dalam sistem endokrin yang terjadi selama kehamilan, terutama disebabkan oleh tingginya fluktuasi kadar Human Chorionic Gonadotrophin (HCG). Periode mual dan muntah yang paling umum adalah pada 12-16 minggu pertama. Adapun faktor yang mempengaruhi emesis gravidarum pada ibu hamil trimester I antara lain faktor fisiologis dan faktor predisposisi. ${ }^{9}$

Emesis gravidarum diawali dengan stimulasi pusat muntah di medula yang mengendalikan otot polos dalam dinding lambung dan otot skeletal di abdomen serta sistem pernafasan, dan zona pemicu kemoreseptor berada diluar sawar darah otak zona pemicu kemoreseptor. Kemoreseptor tersebut juga bertanggung jawab atas terjadi mual dan muntah akibat pergerakan. Stimulus dalam zona pemicu kemoreseptor dihantarkan ke pusat muntah yang menyebabkan otot dalam saluran gastrointestinal dan pernafasan memulai terjadinya muntah. ${ }^{4}$

Hasil penelitian juga menunjukkan bahwa sebagian besar responden dilihat dari status gravida adalah primi gravida. Primigravida belum mampu beradaptasi dengan hormon estrogen dan koreonik gonadotropin sehingga lebih sering terjadi emesis gravidarum. Sedangkan pada multigravida dan grandemultigravida sudah mampu beradaptasi dengan hormon estrogen dan koreonik gonadotropin karena sudah mempunyai pengalaman terhadap kehamilan dan melahirkan.

Mual dan muntah dapat menimbulkan kekhawatiran pada primigravida maupun multigravida. Emosi selama kehamilan, baik 
pada individu maupun pada beberapa wanita serta kekhawatiran yang dialami oleh primigravida menunjukkan kurangnya pengetahuan, informasi dan komunikasi antara wanita dan pemberi asuhannya yang turut mempengaruhi persepsi wanita tentang gejala mual dan muntah. Sedangkan pada multigravida dan grandemultigravida sudah mempunyai pengalaman, informasi dan pengetahuan tentang gejala emesis gravidarum sehingga mampu mengatasi gejalanya.

Hal tersebut menjelaskan mengapa wanita primigravida tampak lebih sering memerlukan hospitalisasi dibandingkan wanita multigravida dan grandemultigravida, meskipun wanita dalam kehamilan berikutnya dapat disibukkan dengan anak lain. Telah terbukti bahwa kebutuhan untuk perawatan di Rumah Sakit meningkat dengan semakin besarnya keparahan dan durasi emesis gravidarum terutama pada primigravida. ${ }^{9}$

Efektifitas pemberian minuman jahe dalam menurunkan emesis gravidarum pada ibu hamil trimester I di BPM Yayuk, S Desa Dlanggu Kabupaten Mojokerto.

Hasil penelitian menunjukkan pemberian minuman jahe efektif dalam mengurangi keluhan emesis gravidarum pada ibu hamil trimester I. Efek antiemetik jahe disebabkan oleh kerja antikolinergik dan anthistamin yang efektif digunakan dalam terapi mencegah mual dan muntah. Jahe adalah pengobatan herbal yang telah digunakan dalam fitoterapi Eropa dan dalam pengobatan tradisional Cina karena kandungan karminatifnya. ${ }^{5}$

Produk terapeutik diturunkan dari rizoma yang diyakini mengandung analgesic, antiinflamasi, antitrombotik, spasmolitik, absorben dan minyak atsiri yang bersifat aromatik dan dapat memberikan pengaruh langsung pada saluran gastrointestinal Efek antimetiknya diduga disebabkan oleh kerja antikolinergik dan antihistamine. ${ }^{2}$ Khasiat anti muntah dari jahe telah pula dibuktikan secara ilmiah. Jahe terbukti sangat berguna dalam mengalami mual dan muntah karena kehamilan, akan tetapi terapi komplementer yang diberikan sendiri salah satunya yaitu minuman jahe ini harus diimbangi dengan terapi lain seperti terapi konvensional yaitu istirahat atau relaksasi, makan sedikit tapi sering, hindari makan tertentu dan hindari hipoglikemia. bahkan dalam bentuk yang paling parah yaitu Hiperemesis Gravidarum, suatu kondisi yang bisanya membutuhkan rawat inap.

Pada uji coba double-blind, jahe mampu menurunkan tingkat keparahan yang signifikan baik rasa mual maupun jumlah serangan muntah terhadap perempuan di awal masa kehamilan (kurang dari 20 minggu). Tidak seperti obat-obat anti-muntah, yang dapat menyebabkan cacat lahir parah, jahe sangatlah aman, dan hanya sejumlah kecil dosis yang diperlukan. ${ }^{2}$

Nasehat yang paling baik untuk ibu hamil adalah bahwa tidak ada obat yang harus digunakan selama kehamilan, tetapi beberapa penyakit ringan yang umum sering memerlukan terapi konvensional untuk membuat ibu merasa nyaman. ${ }^{8}$ Disamping itu, ramuan tradisional juga bisa digunakan sebagai terapi yaitu dengan meminum wedang jahe hangat namun, terapi ini harus diimbangi dengan istirahat atau relaksasi, makan sedikit tapi sering, hindari makan tertentu dan hindari hipoglikemia.

\section{SIMPULAN}

Minuman jahe efektif dalam mengurangi emesis gravidarum pada ibu hamil trimester I karena kandungan minyak atsiri yang bersifat aromatik memberikan pengaruh langsung pada saluran gastrointestinal, sedangkan efek antiemetik pada jahe disebabkan oleh kerja antikolinergik dan anthistamin.

\section{SARAN}

1. Bagi Tenaga Kesehatan

Tenaga kesehatan dapat mengaplikasikan hasil penelitian ini pada ibu hamil yang mengalami emesis gravidarum dengan dosis yang tepat.

2. Bagi Peneliti

Peneliti selanjutnya dapat membuat desain kemasan jahe yang lebih bervariasi, bentuk lain yang lebih menarik sehingga jahe dapat menjadi alternatif untuk mengurangi gejala emesis gravidarum dengan berbagai jenis sediaan tanpa mengurangi khasiat yang terkandung didalamnya. 


\section{KEPUSTAKAAN}

1. Astuti, Maya. 2010. Buku pintar kehamilan. Jakarta: EGC.

2. Budhawaar, Vikaas. 2006. The Secret Benefits of Ginger and Turmeric. Jakarta: PT. Bhuana ilmu populer.

3. Hidayanti, Ratna. 2009. Asuhan Keperawatan pada Kehamilan Fisiologis dan patologis. Jakarta: Selemba medika.

4. Laura, M. 2009. Mengusir Morning Sickness. Kompas. http://www.nasionalkompas.com.index.p hp.

5. Nurmalina, Rina. 2012. 24 Herbal Legendaris untuk Kesehatan Anda. Jakarta: Gramedia.

6. Rubin, Peter. 1999. Prescribing in Pregnancy. Jakarta: Hipokrates.

7. Saswita, Dewi Yulia. 2011. Efektifitas Minumann Jahe dalam Mengurangi Emesis Gravidarum pada Ibu Hamil Trimester http://www.ejournal.unri.ac.id/index.php/ JNI/article/view/634/627. Diakses: Februari 2014.

8. Sulistyawati, Ari. 2009. Asuhan Kebidanan pada Masa Kehamilan. Jakarta: Salemba medika.

9. Tiran, Denise. 2008. Nausea and Vomiting in Pregnancy: An Integrated Approach to Car. Jakarta: EGC.

10. Yance, dkk. 2010. 1001 tentang Kehamilan. Cetakan ke 9. Bandung: PT Triexs Media 